\title{
Correction to: Challenges and ways forward in pesticide emission and toxicity characterization modeling for tropical conditions
}

\author{
Céline Gentil $^{1,2} \cdot$ Peter Fantke $^{3} \cdot$ Charles Mottes $^{1,4} \cdot$ Claudine Basset-Mens $^{1,2}$
}

Published online: 28 April 2021

(c) The Author(s) 2021

\section{Correction to: Int J Life Cycle Assess (2020) 25:1290-1306 https://doi.org/10.1007/s11367-019-01685-9}

The article [Challenges and ways forward in pesticide emission and toxicity characterization modeling for tropical conditions], written by [Céline Gentil, Peter Fantke, Charles Mottes \& Claudine Basset-Mens], was originally published electronically on the publisher's internet portal on [13 September 2019] without open access. With the author(s)' decision to opt for Open Choice the copyright of the article changed on [ 16 November 2020] to () [ The Author(s) 2019] and the article is forthwith distributed under a Creative Commons Attribution which permits use, sharing, adaptation, distribution and reproduction in any medium or format, as long as you give appropriate credit to the original author(s) and the source, provide a link to the Creative Commons license, and indicate if changes were made. The original article has been corrected. Open Access This article is licensed under a Creative Commons Attribution 4.0 International License, which permits use, sharing, adaptation, distribution and reproduction in any medium or format, as long as you give appropriate credit to the original author(s) and the source, provide a link to the Creative Commons licence, and indicate if changes were made. The images or other third party material in this article

The online version of the original article can be found at https:// doi.org/10.1007/s11367-019-01685-9.

Céline Gentil

celine.gentil-sergent@itab.asso.fr

1 HortSys, Univ Montpellier, CIRAD, Montpellier, France

2 CIRAD, UPR HortSys, ELSA, F-97285 Le Lamentin, Martinique, France

3 Quantitative Sustainability Assessment, Department of Technology, Management and Economics, Technical University of Denmark, Kgs. Lyngby, Denmark

4 CIRAD, UPR HortSys, F-97285 Le Lamentin, Martinique, France are included in the article's Creative Commons licence, unless indicated otherwise in a credit line to the material. If material is not included in the article's Creative Commons licence and your intended use is not permitted by statutory regulation or exceeds the permitted use, you will need to obtain permission directly from the copyright holder. To view a copy this licence, visit http://creativecommons.org/ licenses/by/4.0/.

Open Access This article is licensed under a Creative Commons Attribution 4.0 International License, which permits use, sharing, adaptation, distribution and reproduction in any medium or format, as long as you give appropriate credit to the original author(s) and the source, provide a link to the Creative Commons licence, and indicate if changes were made. The images or other third party material in this article are included in the article's Creative Commons licence, unless indicated otherwise in a credit line to the material. If material is not included in the article's Creative Commons licence and your intended use is not permitted by statutory regulation or exceeds the permitted use, you will need to obtain permission directly from the copyright holder. To view a copy of this licence,visit http://creativecommons.org/licenses/by/4.0/. 